\title{
Removal of Fe (III) from Aqueous Solution Using Thiosalcylic Acid as an Efficient and Novel Adsorbent
}

\author{
A.I. Abd-Elhamid ${ }^{1^{*}}$ and H. F. Aly ${ }^{2}$ \\ ${ }^{1}$ Composite and Nanomaterials Department, Advanced Technology and New Materials \\ Research Institute, City for Scientific Research and Technology Applications, P. O. \\ Box 21934, SRTA, Egypt. \\ ${ }^{2}$ Hot Laboratories Center, Atomic Energy Authority, Nasr 13759, Egypt.
}

\begin{abstract}
$\mathbf{T}$ HE REMOVAL of Fe (III) from aqueous solution using thiosalcylic acid (TSA) as adsorbent have been demonstrated in this work. TSA was Characterized by SEM, EDX, FTIR and XRD. Various factors affecting the removal include the contact time, initial concentration of ions, adsorbent dose, initial $\mathrm{pH}$ and temperature have been studied. The experimental data showed that, the removal percent of Fe (III) ion is increased by increasing contact time, adsorbent dose and $\mathrm{pH}$ values. The sorption reaction was found to obey a pseudo second-order rate model with $\mathrm{q}_{\mathrm{e}}=275.78 \mathrm{mg} \mathrm{g}^{-1}$. The sorption isotherms data fit Langmuir and Freundlich models. The waste solid from the adsorption process (thiosalcylic acid adsorbed $\mathrm{Fe}$ (TSA-Fe)) successful in removal of methylene blue (MB) and crystal violet (CV) dyes from binary system.
\end{abstract}

Keywords: Thiosalcylic acid, Fe (III), TSA-Fe, Dye.

\section{Introduction}

Iron is the fourth most common element in the Earth's crust. It is a very important in human nutrition, where iron forms complexes with molecular oxygen in hemoglobin and myoglobin; these two compounds are common oxygen transport proteins in vertebrates. Estimates of the minimum daily requirement for iron depend on age, sex, physiological status and iron bioavailability (range from about 10 to $50 \mathrm{mg}$ / day). The natural fresh waters contain iron at levels ranging from 0.5 to $50 \mathrm{mg} /$ liter and the drinking-water contaminated by iron as a result of the use of iron coagulants or the corrosion of steel and cast iron pipes during water distribution. World Health Organization (WHO) has set a guideline value of the iron in drinking-water about $2 \mathrm{mg} /$ liter, which does not present a hazard to health. [1].

Recently, pollution and nutritional studies highly interest in studying the toxicity and the effect of trace elements on human health and the environment. The removal of iron from drinking water was carried out via several methods such as, ion exchange and water softening [2], activated carbon and other filtration materials [3], supercritical fluid extraction [4], bioremediation [5] and limestone treatment [6], oxidation by aeration, chlorination, ozonation followed by filtration [7], by ash [8], by aerated granular filter [9] and by adsorption [10].

Nowadays, adsorption has been shown to be a cost effective technique for the removal of trace metals from wastewater and water supplies, such as $\mathrm{UO}_{2}^{+2}$ ion [11] and $\mathrm{Cd}(\mathrm{II})$ and $\mathrm{Pb}(\mathrm{II})$ under estuarine and seawater conditions [12], $\mathrm{Cu}^{+2}$ [13], $\mathrm{Pb}^{+2}[14], \mathrm{Fe}(\mathrm{II})$ and $\mathrm{Mn}(\mathrm{II})$ [15], Cr(III) [16] and $\mathrm{Ni}(\mathrm{II})$ [17].

Different materials such as Clays, oxides and other colloidal materials were supplied to control the concentration of trace soluble metal in the heterogeneous systems. It is greatly significance to use a new promising solid sorbents for adsorption of toxic metal ions from aqueous solutions, e.g., Thiosalcylic acid as an efficient adsorbing material with suitable active groups $(-\mathrm{COOH}$ and $-\mathrm{SH}$ ) that interact with metal ions, stable under highly acidic conditions, (slightly soluble in water, ethanol and diethyl ether, and alkanes, but more soluble in DMSO)[18]. Moreover, TSA has fast, quantitative sorption, elution, high mass exchange and capacity. 
Several literatures reported that TSA and its derivative have ability to form a complex with metal ions, e.g. copper(II) with thiosalicylic acid and pyridine [19], copper(II) complexes with S-alkyl derivatives of thiosalicylic acid [20], gold(III)-thiosalicylate and-salicylate complexes [21], palladium(II)-thiosalicylate complexes [22], Cobalt and Thiosalicylic Acid [23] and triphenylphosphine-mercury(II) thiosalicylate complexes [24]. This report studies the removal of Fe (III) from aqueous solution using TSA as a novel and efficient adsorbent. TSA-Fe produced as a waste solid form the adsorption process subjected to remove of MB and CV dyes in binary system from aqueous solution.

\section{Experimental}

\section{Materials}

Thiosalcylic acid (Acros, 98\%), Iron (III) chloride anhydrous (Fisher Scientific, UK., Laboratory reagent grade), Sodium thiocyanate (LOBA chemie PVT.LTD., Extra pure). All chemicals were used without further purification.

\section{Preparation of Adsorbent}

Thiosalcylic acid used without any further purification, milled using ceramic mortar to obtain powder with desired fineness.

\section{Batch adsorption}

Adsorption experiments were conducted by varying contact time, initial $\mathrm{Fe}^{3+}$ concentration, TSA dose, initial $\mathrm{pH}$ and temperature under the aspects of adsorption isotherms and adsorption kinetics. The experiments were carried out in $100 \mathrm{~mL}$ glass beaker and the total volume of the reaction mixture was kept at $25 \mathrm{ml}$. The contact time was varied from 0 to $15 \mathrm{~min}$. $\mathrm{Fe}^{3+}$ solutions of different concentrations, i.e. from 1000 to $3000 \mathrm{ppm}$. The adsorbent dose in rang 0.01 to 0.1 $\mathrm{g} / 25 \mathrm{ml}$. The $\mathrm{pH}$ of the solution was maintained at a desired value by adding $0.1 \mathrm{M} \mathrm{NaOH}$ or $\mathrm{HCl}$.

At predetermined time, $0.5 \mathrm{ml}$ of the solution was withdrawn from the beaker and centrifuged at 5000rpm. The concentration of iron before and after sorption was then determined by the thiocyanate method using UV/Visible spectrophotometer (Double beam) (T80+, PG Instruments Ltd., UK.). The \% removal of iron was calculated using the following expression;

$\% \mathbf{R}=\frac{\left(\mathbf{C}_{\mathbf{o}}-\mathbf{C}_{\mathbf{t}}\right)}{\mathbf{C}_{\mathbf{o}}} \times 100$

Where, $\mathrm{C}_{\mathrm{o}}$ and $\mathrm{C}_{\mathrm{t}}$ are the initial concentration and the concentration of $\mathrm{Fe}^{3+}$ ion at time t, respectively.

Egypt.J.Chem. 61, No.4 (2018)

\section{The decolorization activity of TSA-Fe}

Briefly, $50 \mathrm{mg}$ of the waste solid of the previous adsorption process (TSA-Fe) was added to $10 \mathrm{~mL}$ of $\mathrm{MB}=25 \mathrm{mg} / \mathrm{L}$ and $\mathrm{CV}=25 \mathrm{mg} / \mathrm{L}$ in a binary system in the presence of $300 \mu \mathrm{L}$ of hydrogen peroxide $\left(\mathrm{H}_{2} \mathrm{O}_{2}\right)$ at room temperature. The degradation or decolorization of methylene blue and crystal violet was monitored by a UVvisible spectrophotometer $(\lambda=662 \mathrm{~nm}$ for $\mathrm{MB}$ and $\lambda=590 \mathrm{~nm}$ for $\mathrm{CV}$ ) at different reaction periods.

\section{Characterization}

The characterization of the mortared TSA was carried out by Scanning Electron Microscope (SEM, JSM-636 OLA, Jeol, Japan.), Fourier Transmission Infrared Spectroscopy (FT-IR, 8400 s, Shimadzu, Japan) covered the range from $400-4000 \mathrm{~cm}^{-1}$. IR spectra of solid samples were detected using the $\mathrm{KBr}$ disc. X-Ray Diffraction (XRD, XRD-7000 Shimadzu, Japan) was utilized to estimate crystalline structure of the prepared nanoparticles. EDX used to determine the elemental analysis.

\section{Results and Discussion}

Morphology and chemical properties of TSA

Figure 1a-c, shows the SEM images at different magnification $(300 x, 1000 x$ and 15000x) of the as-obtained TSA with high resolution SEM. The particlesTSA appear well dispersed, with spherical shape and uniform size with an average size of 3.8 $\mu \mathrm{m}$. The elemental analysis (EDX) of thiosalcylic acid (TSA) and thiosalcylic acid adsorbed $\mathrm{Fe}^{3+}$ (TSA-Fe) were investigated in Fig. 1d and e, respectively. The resulted data showed that, the TSA composed of (7C: 2O: 1S; 69\%: 21\%: 9\%) and TSA-Fe possess similar composition of TSA with the presence of $\mathrm{Fe}$. The Chemical structure of TSA was investigated by FTIR spectra (Fig. 1f). In which the peak at $3,452 \mathrm{~cm}^{-1}$ attributed to $\mathrm{OH}(\mathrm{SH})$ stretching vibration and the peak at $1,653 \mathrm{~cm}^{-1}$ to $\mathrm{OH}$ bending vibration indicate the existence of adsorbed water molecules and structural $\mathrm{OH}$ groups [25]. The next relatively strong bands at $2,955 \mathrm{~cm}^{-1}$ and $2,874 \mathrm{~cm}^{-1}$ may be corresponding to the $\mathrm{C}-\mathrm{H}$ stretching vibration of $\mathrm{CH}_{2}$ groups. Therefore, the band at $1,435 \mathrm{~cm}^{-1}$ ascribed to the $\mathrm{OH}$ deformation vibration of $\mathrm{COOH}$ groups. The bands at $1,280 \mathrm{~cm}^{-1}$ and 1,031 $\mathrm{cm}^{-1}$ are corresponded to $\mathrm{C}-\mathrm{O}-\mathrm{C}$ and $\mathrm{OH}$ [26]. The crystal structure of TSA was explained using $\mathrm{X}$-ray diffraction (XRD). The results showed that TSA has crystalline structure as illustrated in Fig. $1 \mathrm{c}$. 

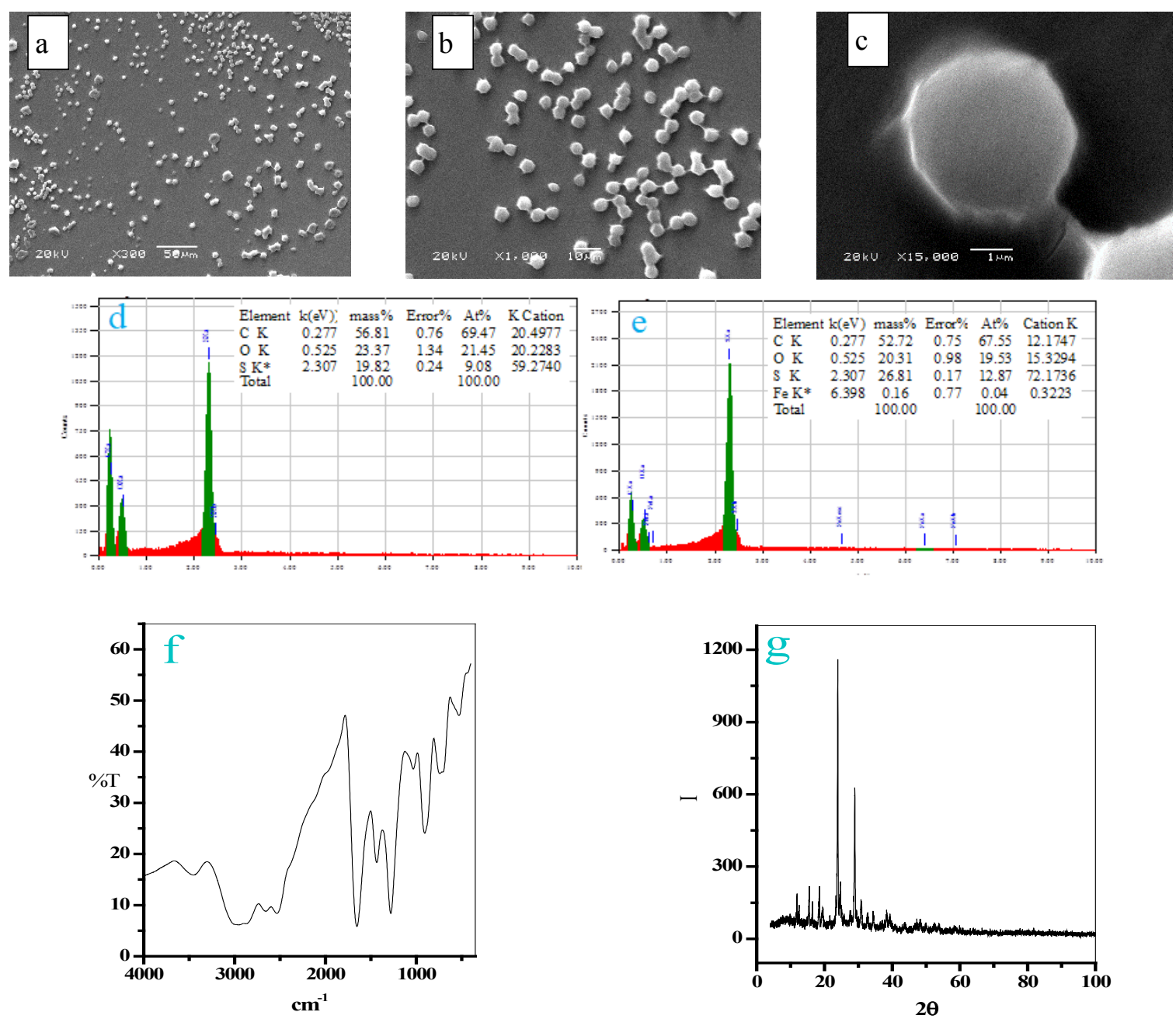

Fig. (1). (a-c) SEM image at different magnifications of pure TSA, d) EDX-analysis of pure TSA, e) EDX-analysis of TSA adsorbed $\mathrm{Fe}^{3+}$ (TSA-Fe), d) FTIR of the pure TSA, and c) XRD of the pure TSA.

\section{Adsorption process}

\section{Contact Time}

The relationship between contact time and removal percent of $\mathrm{Fe}^{3+}$ from aqueous solution onto TSA particles at ([Fe (III)]: 1000 ppm, Dose: $0.10 \mathrm{~g} / 25 \mathrm{~m}, \mathrm{pH}: 2.5$ and Temperature: $20^{\circ} \mathrm{C}$ ) is explained in Fig. 2a. The adsorption was initially fast (i.e., first $10 \mathrm{~min}$ ), with progressive time (10$15 \mathrm{~min})$ it reaches equilibrium. The initial fast adsorption might be referred to the large number of binding sites are available at the adsorption startup; as the adsorption sites were gradually filled up, the adsorption became stable.

\section{Adsorption reaction models}

The relationship between the adsorption rate of the adsorbate and the adsorption time, explained by using adsorption kinetics. Two well-known kinetic models, pseudo-first-order presented by
Lagergren equation [27]. Eq. 2.

$$
\log \left(\mathrm{q}_{\mathrm{e}}-\mathrm{q}_{\mathrm{t}}\right)=\log q_{e}+\frac{\mathrm{K}_{\mathrm{ads}} \mathrm{t}}{2.303}
$$

Where, $\mathrm{q}_{\mathrm{e}}(\mathrm{mg} / \mathrm{g})$ is the amount of sorption at equilibrium time, $\mathrm{q}_{\mathrm{t}}(\mathrm{mg} / \mathrm{g})$ is amount of sorption at time and $\mathrm{K}_{\mathrm{ads}}\left(\mathrm{min}^{-1}\right)$ is the rate constant of pseudo first order sorption.

$\mathbf{q}_{\mathrm{e}}=\frac{\left(\mathrm{C}_{\mathrm{o}}-\mathrm{C}_{\mathrm{e}}\right) \mathbf{V}}{1000 \mathrm{w}}$

Where $\mathrm{C}_{\mathrm{o}}$ is the initial concentration $(\mathrm{mg} / \mathrm{L})$, $\mathrm{Ce}$ is the dye concentration at equilibrium time intervals $(\mathrm{mg} / \mathrm{L}), \mathrm{V}$ is the volume of dye solution $(\mathrm{mL})$ and $\mathrm{W}$ is the mass of adsorbent (g.)

$\mathrm{q}_{\mathrm{t}}=\frac{\left(\mathrm{C}_{0}-\mathrm{C}_{\mathrm{t}}\right) \mathrm{V}}{1000 \mathrm{w}}$ 
Where $\mathrm{C}_{\mathrm{t}}$ is the dye concentration at different time intervals $(\mathrm{mg} / \mathrm{L})$

And pseudo-second-order expressed by Ho equation [28] the equation developed in a linear form as;Eq.5.

$\frac{\mathbf{t}}{q_{t}}=\frac{1}{K_{2} q_{e}^{2}}+\frac{t}{q_{e}}$

Where, $\mathrm{K}_{2}\left(\mathrm{~g} \mathrm{mg}^{-1} \mathrm{~min}^{-1}\right)$ is the rate constant of pseudo second order reaction.

The adsorption kinetics of $\mathrm{Fe}^{3+}$ ions by TSA were investigated by three kinetic models which are pseudo 1st order, pseudo 2nd order, and intraparticle diffusion. The pseudo 1 st and 2 nd order plots obtained by plotting $\log \left(\mathrm{q}_{\mathrm{e}}-\mathrm{q}_{\mathrm{t}}\right)$ versus $\mathrm{t}(\mathrm{min})$ (Fig. 2b) and $t / q_{t}$ against $t$ (Fig. $2 c$ ), respectively. The experimental data were calculated and listed in Table1. As compared correlation coefficients $\left(\mathrm{R}^{2}\right)$; the adsorption of $\mathrm{Fe}^{3+}$ was fitted well by $2 \mathrm{nd}$ order pseudo kinetics.

The mechanism and rate controlling step affecting the kinetics of adsorption is determined by fitting the kinetic experimental results by Weber's intraparticle diffusion. The intraparticle model is expressed as:

$\mathrm{q}_{\mathrm{t}}=\mathrm{k}_{\mathrm{p}} \mathrm{t}^{0.5}+\mathrm{C}$

where $\mathrm{C}$ is the intercept and $\mathrm{k}_{\mathrm{p}}$ is the intraparticle diffusion rate constant, $\left(\mathrm{mgg}^{-1} \min ^{-0.5}\right)$, which can be evaluated from the slope of the linear plot of $\mathrm{q}_{\mathrm{t}}$ versus $\mathrm{t}^{0.5}$ as shown in Fig. 2d. The intercept of the plot reflects the boundary layer effect. The larger the intercept, the greater the contribution of the surface sorption in the rate controlling step. However, the regression of $\mathrm{q}_{\mathrm{t}}$ versus $\mathrm{t}^{0.5}$ the linear plot did not pass through the origin. This indicates that the intraparticle diffusion was not only a rate controlling step.

\section{Effect of [Fe]}

Increasing the initial $\mathrm{Fe}^{3+}$ concentration from $1000 \mathrm{ppm}$ to $3000 \mathrm{ppm}$ in solutions with an initial pH 2.5 leads to decrease the percent removal of $\mathrm{Fe}^{3+}$ from about 99 to $22 \%$, as explained in Fig.3a. This can be illustrated by increasing ratios between the initial number of moles of $\mathrm{Fe}^{3+}$ and the limited number of available sorption sites on the TSA.

\section{Equilibrium isotherms studies}

The analysis of the equilibrium adsorption isotherm model is a prerequisite for predicting the adsorption uptake of the adsorbent, which is Egypt.J.Chem. 61, No.4 (2018) one of the main parameters required for designing an optimized adsorption system. Two available isotherm models, that are, the Langmuir [29] and Freundlich [30], are used for this purpose. Applying Langmuir isotherm (by plotting $1 / \mathrm{C}_{\mathrm{e}}$ against $1 / \mathrm{q}_{\mathrm{e}}$ as shown in Fig. $3 \mathrm{~b}$ ) and Freundlich isotherm (by plotting $1 / \mathrm{C}_{\mathrm{e}}$ against $1 / \mathrm{q}_{\mathrm{e}}$ as shown in Fig. 3c); the extracted isotherm information is summarized in Table 2. From the Fig. $3 b$ and $3 c$ as well as the Table 2, it was obvious that both Langmuir and Freundlich models better fitted the experimental equilibrium adsorption data. The Langmuir model postulates a complete monolayer of adsorption, in which there is no transmigration of the adsorbate on the surface plane [29]. This model involves a homogeneous surface with equal energy and equally available sites for adsorption [31]. The Langmuir $\mathrm{q}_{\max }$ value was $217.39 \mathrm{mg} \mathrm{g}^{-1}$. The Freundlich model [30] assumes a heterogeneous adsorption of $\mathrm{Fe}^{3+}$ on the adsorption sites of TSA. The Freundlich intensity constant $\left(1 / \mathrm{n}_{\mathrm{f}}\right)$ is less than unity, indicating a concentration dependent sorption for $\mathrm{Fe}^{3+}$ adsorbed into TSA.

\section{Effect of Dose}

The variations in the adsorption of $\mathrm{Fe}^{3+}$ with the change in the TSA dose using a constant volume of aqueous solution $(25 \mathrm{ml})$ and varying mass of TSA $(0.01-0.10 \mathrm{~g})$ is shown in Fig. 4. The removal percent, $\% \mathrm{R}$, was found to increase sharply with increasing the dose weight from 0.01 to $0.10 \mathrm{~g}$, this is due to as the dose weight increase the active sites available for $\mathrm{Fe}^{3+}$ adsorption increases and hence the $\% \mathrm{R}$ increases $[32,33]$.

\section{Effect of initial $\mathrm{pH}$}

It has been recognized that the adsorption process is highly affected by the $\mathrm{pH}$ of adsorbate solution, this is referring to the $\mathrm{pH}$ not only influencing on the adsorbent surface charge but also on adsorbed species [34-36]. The effect of $\mathrm{pH}$ in the range from 1 to 2.5 on the adsorption of $\mathrm{Fe}^{3+}$ onto TSA is illustrated in Fig.5a. It was observed that the amount adsorbed, $\mathrm{q}_{\mathrm{e}}$, increased with the increase in $\mathrm{pH}$ values. This is can be clarified as seen in Scheme in Fig.5b. Whereby adding $\mathrm{HCl}$ to the reaction mixture it retarded the dissociation reaction of both TSA and $\mathrm{FeCl}_{3}$ by the effect of common ion phenomena. Moreover, the difference between initial $\mathrm{pH}$ and final $\mathrm{pH}$ of the reaction media $\left(\Delta \mathrm{pH}\right.$; i.e. $\mathrm{H}^{+}$ion concentration or liberated $\mathrm{H}^{+}$ion) increase with increase $\mathrm{pH}$ values as illustrated in Fig.5c. 
TABLE 1. Calculated parameters of the pseudo First-order and pseudo Second-order kinetic models.

\begin{tabular}{|c|c|c|c|c|c|c|c|}
\hline \multirow{2}{*}{ Adsorbent } & \multirow{2}{*}{$q_{e \exp }(m g / g)$} & \multicolumn{3}{|c|}{ First-order kinetic parameter } & \multicolumn{3}{|c|}{ Second-order kinetic parameter } \\
\hline & & $K_{1}\left(\min ^{-1}\right)$ & $\mathbf{q}_{\text {e cal }}(\mathrm{mg} / \mathrm{g})$ & $\mathbf{R}^{2}$ & $\mathrm{~K}_{2}\left(\mathrm{~g} \mathrm{mg}^{-1} \mathrm{~min}^{-1}\right)$ & $\mathrm{q}_{\mathrm{ecal}}(\mathrm{mg} / \mathrm{g})$ & $\mathbf{R}^{2}$ \\
\hline $\mathrm{Fe}^{3+}$ & 248.4 & -0.190 & 162.180 & 0.848 & 692.00 & 275.78 & 0.990 \\
\hline
\end{tabular}
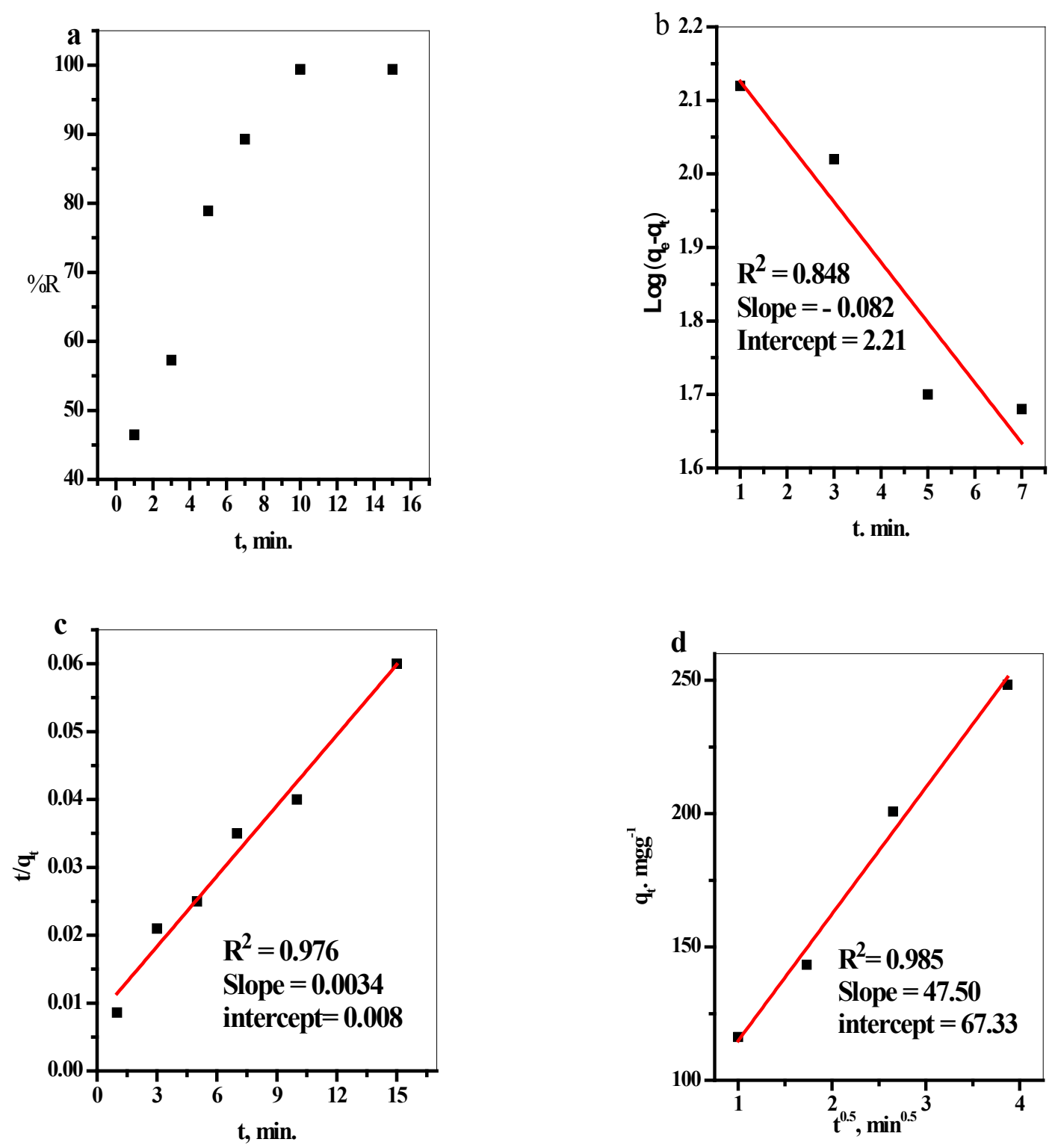

Fig. 2. Effect of a) contact time, b) Pseudo first-order plot, c) Pseudo second-order plot, d) Intraparticle diffusion plot on the removal of $\mathrm{Fe}$ (III) from aqueous solution.
[Fe (III)]: 1000 ppm
Does: $0.10 \mathrm{~g} / 25 \mathrm{ml}$
pH: 2.5
Temperature: $20^{\circ} \mathrm{C}$ 

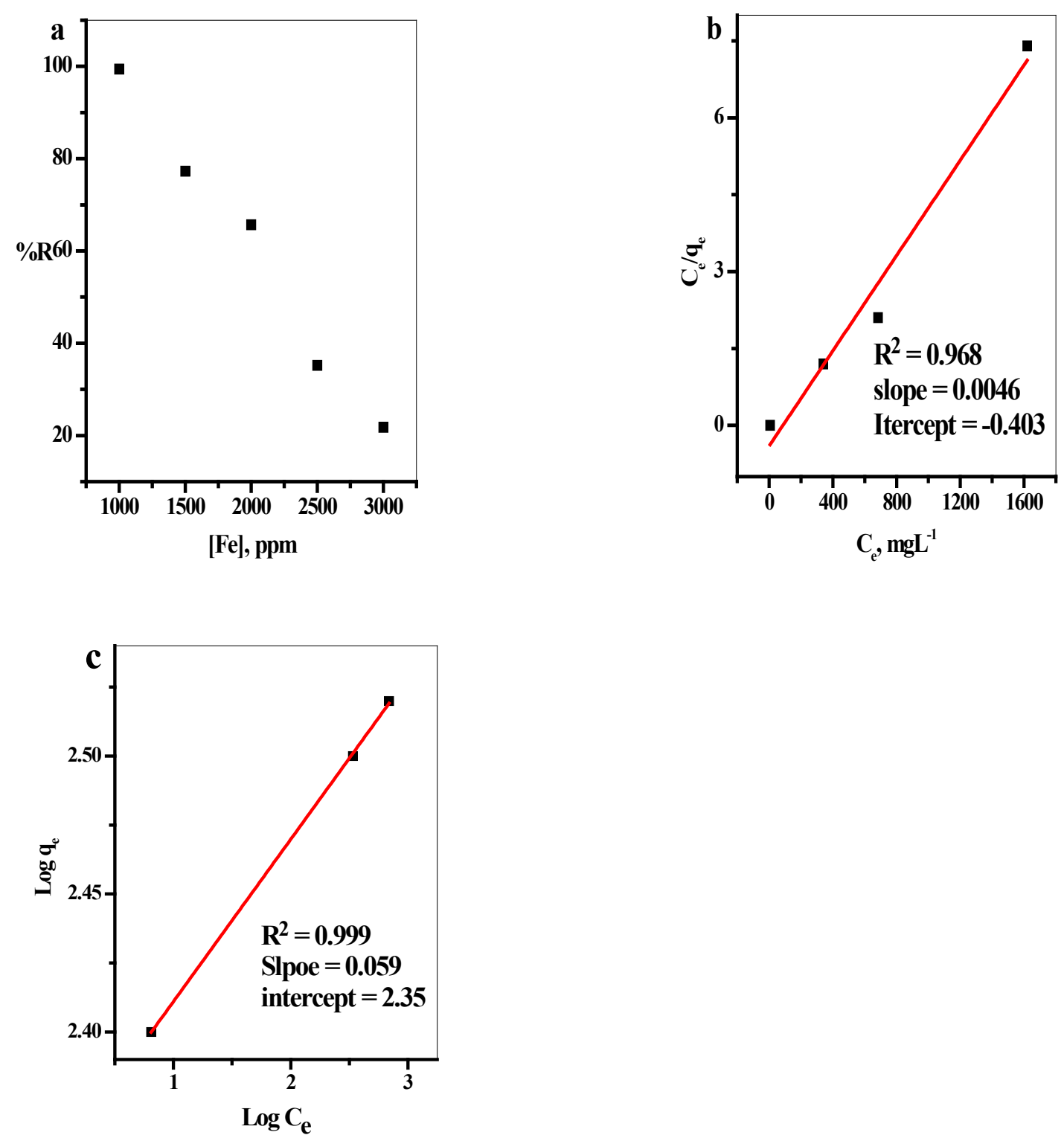

Fig. 3. Effect of a) TSA dose, b) Langmuir adsorption isotherm and c) Freundlich adsorption isotherm on the removal of $\mathrm{Fe}$ (III) from aqueous solution.

Time: $10 \mathrm{~min}$.

pH: 2.5
Dose: $0.10 \mathrm{~g} / 25 \mathrm{ml}$

Temperature: $20^{\circ} \mathrm{C}$

TABLE 2 . Langmuir and Freundlich constants for adsorption of $\mathrm{Fe}^{3+}$ by TSA.

\begin{tabular}{ccccccc}
\hline \multirow{2}{*}{ Adsorbent } & \multicolumn{3}{c}{ Langmuir isotherm model } & \multicolumn{3}{c}{ Freundlich isotherm model } \\
\cline { 2 - 7 } & $\mathrm{q}_{\mathrm{o}}(\mathrm{mg} / \mathrm{g})$ & $\mathrm{K}_{\mathrm{L}}(1 / \mathrm{mg})$ & $\mathrm{R}^{2}$ & $1 / \mathrm{n}_{\mathrm{f}}$ & $\mathrm{K}_{\mathrm{f}}(\mathrm{mg} / \mathrm{g})$ & $\mathrm{R}^{2}$ \\
\hline $\mathrm{Fe}^{3+}$ & 217.39 & -0.011 & 0.968 & 0.059 & 223.87 & 0.999 \\
\hline
\end{tabular}




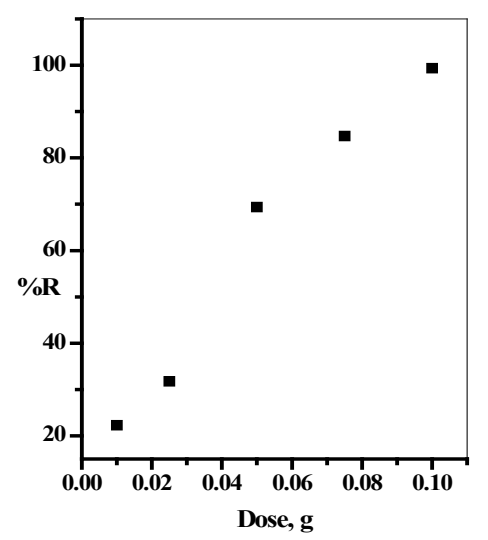

Fig. 4. Effect of TSA dose on the removal of Fe (III) from aqueous solution. Time: $10 \mathrm{~min}$. pH: 2.5

[Fe (III)]: $1000 \mathrm{ppm}$

Temperature: $20^{\circ} \mathrm{C}$

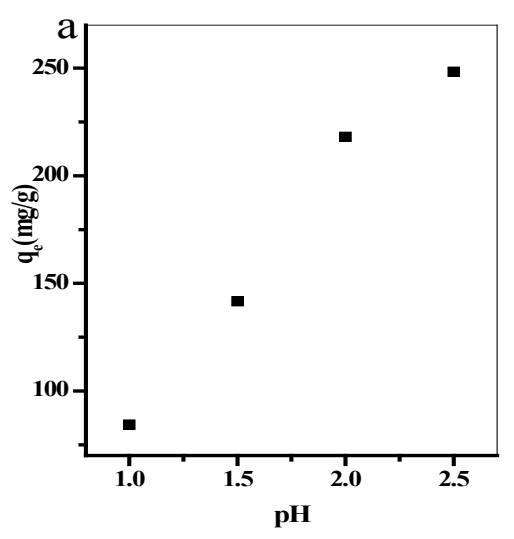

b
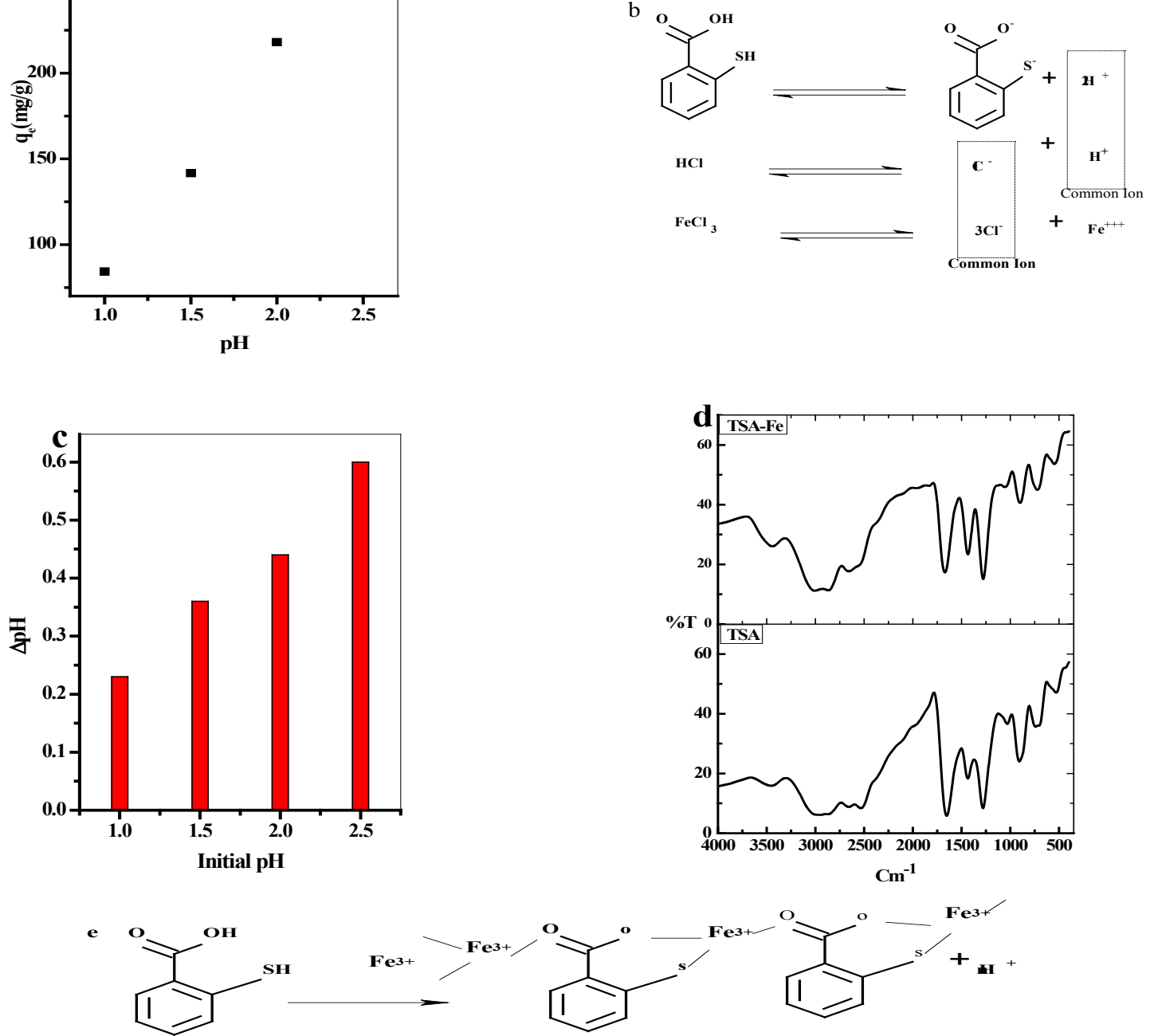

Fig. 5. a) Effect of pH on the adsorption amount of Fe (III) from aqueous solution, b) Scheme of common ion effect, c) Effect of initial pH on the pH difference, d) FTIR of TSA \& TSA-Fe and e) Scheme of Fe $\mathrm{F}^{3+}$ adsorption Time: $10 \mathrm{~min}$. Dose: $0.10 \mathrm{~g} / 25 \mathrm{ml}$ [Fe (III)]: 1000 ppm Temperature: $20^{\circ} \mathrm{C}$ 
By comparing the FTIR- spectrum of TSA and $\mathrm{Fe}$ adsorbed on TSA (TSA-Fe), (Fig. 5d), it is found that the bands at $1653 \mathrm{~cm}^{-1}, 2654 \mathrm{~cm}^{1}$, $2874 \mathrm{~cm}^{-1}$, 2955and $3452 \mathrm{~cm}^{-1}$ were shifted to $1670 \mathrm{~cm}^{-1}, \quad 2658 \mathrm{~cm}^{-1}, 2866 \mathrm{~cm}^{-1}, \quad 3007 \mathrm{~cm}^{-1}$ and $3441 \mathrm{~cm}^{-1}$, respectively. Furthermore, the band at $2534 \mathrm{~cm}^{-1}$ in TSA disappeared upon adsorption of $\mathrm{Fe}(\mathrm{III})$. This variation may be attributed to the adsorption of $\mathrm{Fe}$ (III) and liberation of $\mathrm{H}^{+}$-ions.

Based on the above analysis, the mechanism of Fe (III) adsorption on TSA can be supposed as explained in Scheme in Fig. 5e. As indicated in Fig.5e, the $\mathrm{Fe}^{3+}$ adsorbed on TSA and $\mathrm{H}^{+}-$ ions become free to move to the bulk of solution causing adecrease in solution $\mathrm{pH}$ value.

\section{Effect of temperature}

Figure 6 illustrates that the amount of $\mathrm{Fe}^{3+}$ adsorbed onto TSA does not influence by further increase in the temperature.

\section{Decolorization Activity of TSA-FE}

The decolorization activity of the MB and $\mathrm{CV}$ dyes from binary system using TSA-Fe in the presence of $\mathrm{H}_{2} \mathrm{O}_{2}$ was investigated. The UVvis- spectrum (Fig7a) showed the decrease of the maximum peaks at $662 \mathrm{~nm}$ (for MB-dye) and $590 \mathrm{~nm}$ (for CV-dye) within the time range (0.0-60.0 min). The plot Ln A / A vs t (Fig. 7b) gives a linear relation, its slope expressed as the first order rate constant $(\mathrm{k})$. it's necessary to note that the decolorization rate constant for $\mathrm{CV}(\mathrm{k}=$ $\left.0.043 \mathrm{~min}^{-1}\right)$ is two times of $\left(\mathrm{k}=0.026 \mathrm{~min}^{-1}\right)$ for MB. To conclude, in this study, we report the first trial to use the waste solid from the adsorption process in another application process without any further purification.

\section{Conclusion}

The results of ion sorption indicated that TSA is an efficient sorbent for the removal of $\mathrm{Fe}^{3+}$ ion from aqueous media. The removing of $\mathrm{Fe}^{3+}$ ion by the sorbent material carried out via pseudo $1^{\text {st }}, 2^{\text {nd }}$, particle diffusion mechanism, Langmuir, Freundlich models are the best choice to describe the observed equilibrium data. The results show that TSA is effective in removal of $\mathrm{Fe}^{3+}$ ion in a wide range of concentration. Finally, TSA-Fe, from the adsorption process shows an active behavior towards the removal of (MB\&CV-dyes) from binary system.

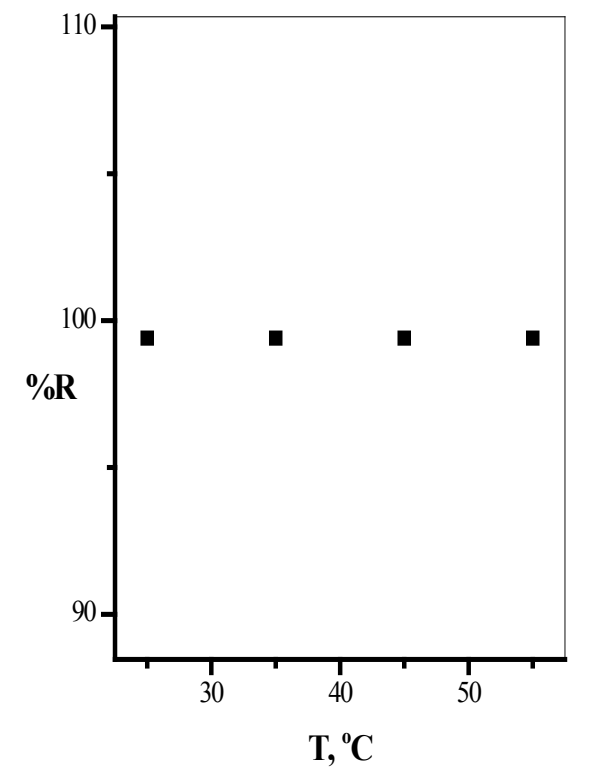

Fig. 6. Effect of temperature on the removal of Fe (III) from aqueous solution.

Time: $10 \mathrm{~min}$.

Does: $0.10 \mathrm{~g} / 25 \mathrm{ml}$
[Fe (III)]: 1000 ppm

pH: 2.5

Egypt.J.Chem. 61, No.4 (2018) 

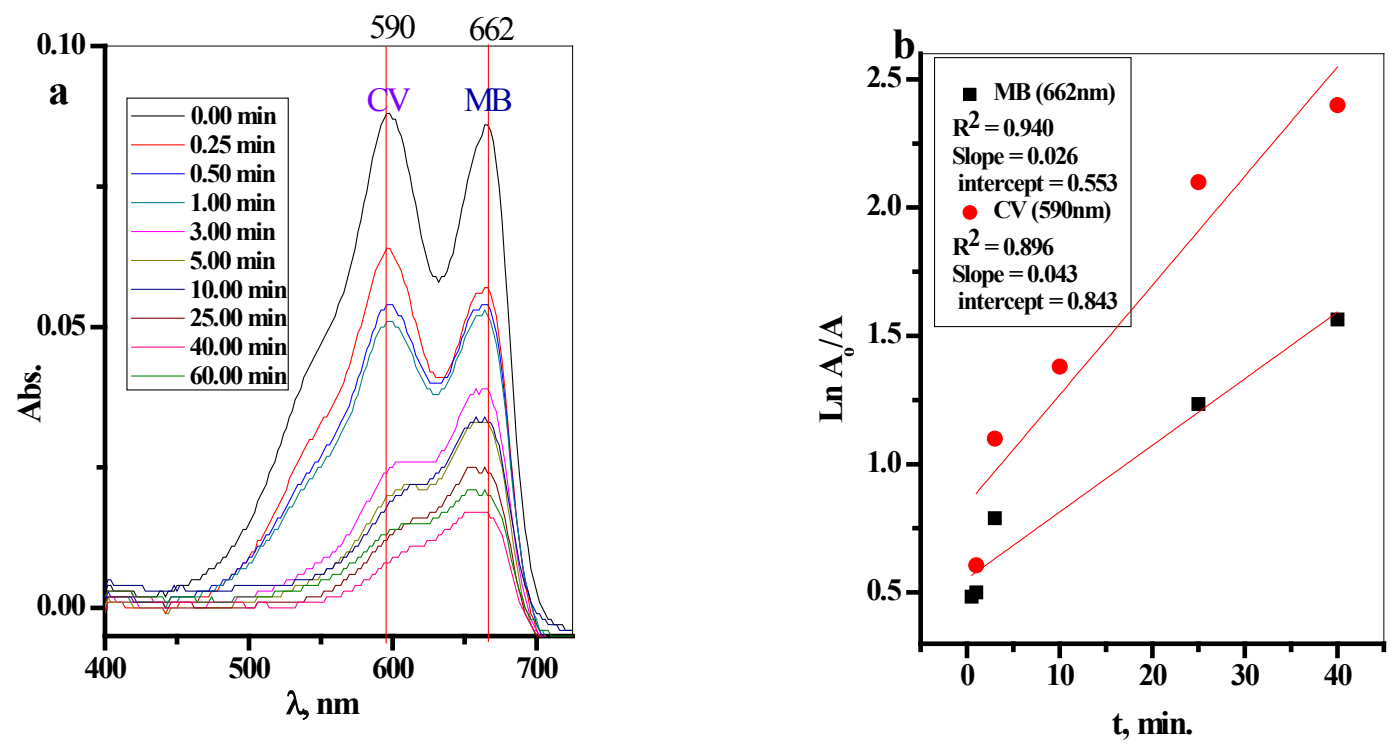

Fig. 7. Effect of time on the reaction kinetic (TSA-Fe dose $=50 \mathrm{mg},\left[\mathrm{H}_{2} \mathrm{O}_{2}\right]=300 \mu \mathrm{l},[\mathrm{MB}]=[\mathrm{CV}]=25 \mathrm{mg} / \mathrm{L}$, dye solution volume $=10 \mathrm{ml}, \mathrm{T}=25^{\circ} \mathrm{C}$.

\section{References}

1. WHO (2003) Iron in drinking-water. Background document for preparation of WHO Guidelines for drinking-water quality. Geneva, World Health Organization (WHO/SDE/WSH/03.04/8).

2. Vaaramaa, K., Lehto, J., Removal of metals and anions from drinking waterby ion exchange, Desalination, 155, 157-170(2003).

3. Munter, R., Ojaste, H., Sutt, J., Complexed iron removal from ground water, Journal of Environmental Engineering, 131, 1014-1020 (2005).

4. Andersen, W.C., Bruno, T.J., Application of gas-liquid entraining rotor tosupercritical fluid extraction: removal of iron(III) from water, Analytical Chimica Acta, 485, 1-8 (2003).

5. Berbenni, P., Pollice, A., Canziani, R., Stabile, L., Nobili, F., Removal of iron and manganese from hydrocarbon-contaminated ground waters, Bioresource Technology, 74, 109-114 (2000).

6. Aziz, H.A., Yusoff, M.S., Adlan, M.N., Adnan, N.H., Alias, S., Physicochemical removal of iron from semiaerobic landfill leachate by limestone filter, Water Management, 24, 353-358(2004).

7. Ellis, D., Bouchard, C., Lantagne, G., Removal of iron and manganese from groundwater by oxidation and microfiltration, Desalination, 130, 255-264 (2000).

8. Das, B., Hazarika, P., Saikia, G., Kalita, H.,
Goswami, D.C., Das, H.B., Dube, S.N., Dutta, R.K., Removal of iron from groundwater by ash, a systematic study of a traditional method, Journal of Hazardous Materials, 141, 834-841(2007).

9. Cho, B.Y., Iron removal using aerated granular filter, Process Biochemical, 40, 3314-3320 (2005).

10. Tahir, S.S., Rauf, N., Removal of $\mathrm{Fe}^{2+}$ from the waste water of a galvanized pipe manufacturing industry by adsorption onto bentonite clay, Journal of Environmental Management, 73, 285292 (2004).

11. Olguin, M., Solache-Rios, M., Acosta, D., Bosch, P., Bulbulian, S., $\mathrm{UO}_{2}^{+2}$ sorption on bentonite. Journal of Radioanalytical Nuclear Chemistry, 218, 65-69 (1997).

12. Kozar, S., Bilinski, H., Branica, M., Schwugar, M.J., Adsorption of $\mathrm{Cd}(\mathrm{II})$ and $\mathrm{Pb}(\mathrm{II})$ on bentonite under estuarine and seawater conditions. Science of the Total Environment, 121, 203-216 (1992).

13. Rauf, N., Ikram, M., Tahir, S.S., Adsorption studies of $\mathrm{Cu}(\mathrm{II})$ from aqueous/acidic solutions onto bentonite. Adsorption Science Technology, 17, 431-440 (1999).

14. Naseem, R., Tahir, S.S., Removal of lead (II) form aqueous/acidic solutions by using bentonite as an adsorbent. Journal of Water Research, 35, 39823986 (2001).

15. Naseem, R., Tahir, S.S., Thermodynamic studies of $\mathrm{Mn}(\mathrm{II})$ and $\mathrm{Fe}$ (II) adsorption on to bentonite.

Egypt.J.Chem. 61, No. 4 (2018) 
Journal of Chemical Thermodynamics, 32, 651658 (2000).

16. Rauf, M.A., Ikram, M., Rauf, N., Trace level removal studies of $\mathrm{Cr}$ (III) from aqueous solution. Journal of Trace Microprobe Technology, 20, 119-125 (2002).

17. Rauf, M.A., Iqbal, J., Ikram, M., Rauf, N., Adsorption studies of $\mathrm{Ni}$ (II) from aqueous solution onto bentonite. Journal of Trace Microprobe Technology. 21 (2003) 337-342.

18. Lide, David R., ed. (2009) CRC Handbook of Chemistry and Physics (90th ed.).

19. Ferrer, E.G., Williams, P.A., Synthesis and characterization of a dimeric complex of $\mathrm{Cu}^{\mathrm{II}}$ with thiosalicylic acid and pyridine, Polyhedron, 16, 3323-3325 (1997).

20. Miloš, V.N., Marina, Ž.M., Verica, V.J., Zoran, R.R., Ivana, D.R., Ljiljana, R.Č., Slađana B. N., Goran, A.B., Srećko, R.T., Gordana, P.R., Synthesis, characterization and antimicrobial activity of copper(II) complexes with some S-alkyl derivatives of thiosalicylic acid. Crystal structure of the binuclear copper(II) complex with S-methyl derivative of thiosalicylic acid, Polyhedron, 79, 80-87 (2014). http://dx.doi.org/10.1016/j.poly.2014.04.053

21. Maarten, B.D., William, H., Organogold(III) metallacyclic chemistry. Part 41. Synthesis, characterisation, and biological activity of gold(III)-thiosalicylate and -salicylate complexes, Journal of Organometallic Chemistry, 560, 233243 (1998).

22. William, H., Louise, J.M.C. Brian, K.N., Synthesis and biological activity of platinum(II) and palladium(II) thiosalicylate complexes with mixed ancillary donor ligands, Journal of Chemical Society, Dalton Transition, 2753-2760 (2000). DOI: 10.1039/b003619f.

23. Kumarh, A.N., Nigam, H.L., Katy, M., Complex Formation between Cobalt and Thiosalicylic Acid, Journal for praktische Chemie. 4. Reihe. Band, 33, 160-164 (1966).

24. William, H., Brian, K.N., Synthesis and X-ray structures of triphenylphosphine-mercury(II) thiosalicylate complexes: novel aggregation processes, Inorganica Chimica Acta, 357, 22312236 (2004).

25. Peichao, L., Xuefeng, Z., Shuzhao, L., Zhong, L., Weishen, Y., Haihui, W., Large reversible capacity of high quality graphene sheets as an anode material for lithium-ion batteries, Electrochimica Acta, 55, 3909-3914 (2010).
26. Yongchao, S., Edward, T.S., Synthesis of Water Soluble Graphene, Nano Letter, 8, 1679-1682 (2008).

27. Lagergren, S., About the theory of so called adsorption of soluble substances. Kungliga Svenska Vetenskapsakad. Handlingar Band, 24, $1-39(1898)$

28. Ho, Y.S., McKay, G., The sorption of lead (II) ions on peat, Water Research, 33, 578 - 584(1999).

29. Langmuir, I., The constitution and fundamental properties of solids and liquids, Journal of American Chemical society, 38 (11), 2221-2295 (1916).

30. Freundlich, H.M.F., Over the Adsorption in Solution, Journal of Physical Chemistry, 57, 385471 (1906).

31. Vargas, A.M.M., Cazetta, A.L., Kunita, M.H., Silva, T.L., Almeida, V.C., Adsorption of methylene blue on activated carbon produced from flamboyant pods (Delonix regia): Study of adsorption isotherms and kinetic models, Chemical Engineering Journal,168, $722-730$ (2011).

32. Adriana, S.F., Leandro, S.O., Mauro, E.F., Kinetics and equilibrium studies of methylene blue adsorption by spent coffee grounds, Desalination, 249, 267-272 (2009).

33. Farook A., Lingeswarran M., Radhika T., Ceria and titania incorporated silica based catalyst prepared from rice husk: Adsorption and photocatalytic studies of methylene blue, Journal of Colloid and Interface Science, 406, 209-216 (2013).

34. Abuzer, C., Gizem, I., Hüseyin, B., Sorption equilibrium, kinetic, thermodynamic, and desorption studies of Reactive Red 120 on Chara contraria, Chemical Engineering Journal, 191, 228-235 (2012).

35. Abuzer, C., Barıs, T., Hüseyin, B., Predictive modeling of removal of Lanaset Red $\mathrm{G}$ on Chara contraria; kinetic, equilibrium, and thermodynamic studies, Chemical Engineering Journal, 169, 166172(2011).

36. Kumar, P.S., Ramalingam, S., Senthamarai, C., Niranjanaa, M., Vijayalakshmi, P., Sivanesan, S., Adsorption of dye from aqueous solution by cashew nut shell: Studies on equilibrium isotherm, kinetics and thermodynamics of interactions, Desalination, 261, 52-60 (2010).

(Received 25/3/2018; accepted 21/5/2018) 


\section{إزالة الحديد الثثلاثى من المحلول المائى بإستخدام حمض الثيوسلسيلك كممتز ذو كفاءة عالية}

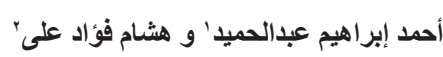

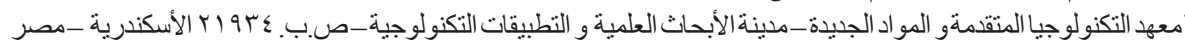

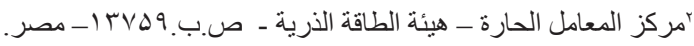

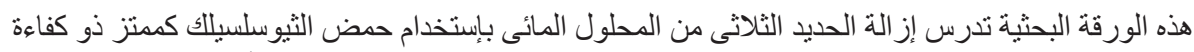

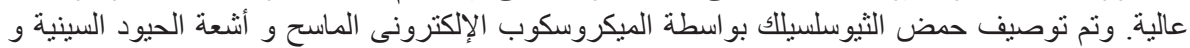

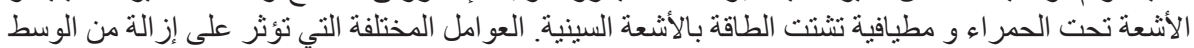

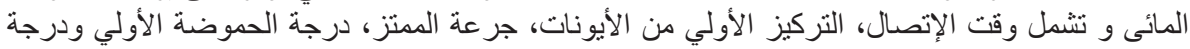

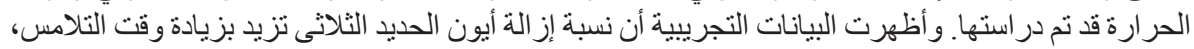

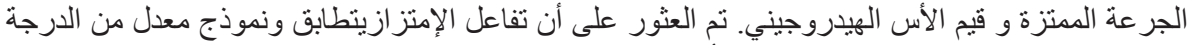

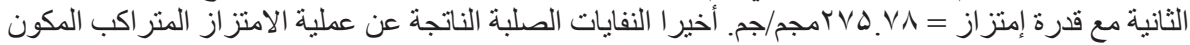
من (حض ثيوسيلسيليك ـ الحديدالثلاثى) نجح في إزالة الصبغة الزرقاء و الصبغة البنفسجية من النظام الثنائي. 